$48-530$

\title{
鼻中隔穿孔，原因㫫二其手術的閉鎖法二就テ
}

\author{
Dr. Shoji Niho: Uber Ursache und operativen \\ Verschluss von Septumperforation.

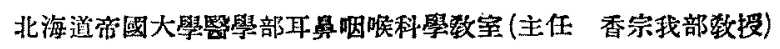 \\ 仁 保 正诰 \\ 第一章 緒言
}

鼻中隔穿孔ハ多クハ後天性二起儿モノ=シ テ・鼾中隔彎曲。櫛又八棘二對スルキりアン氏 粘膜下愙形切除術 晢及七儿今日 =於テハ該手 術時人失收二因儿モ，最モ多シ。一度鼻中隔二 穿孔ヨ生ゼンカ。該第孔八一生涯淺存シ。術者 ノ不名舆ナルコト甚ダシ。

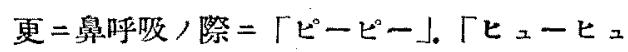
一」等卜笛馨习發スル 大ナリ。

翻ツテ文献 スルモノ八極メテ室々タルモノニシテ，其主ナ ルモノフ㼂グレバャンカウェル，ハルレ氏法。

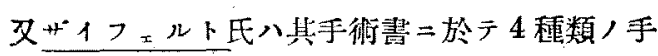

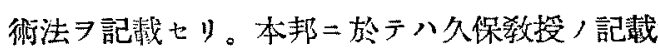
㫕ルノ。

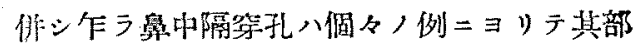

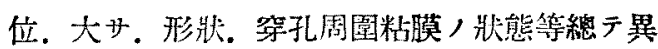
ナルモノニシテ。粘膜軟骨膜瓣，作製法ハ润タ 八場合二適合セル方法ヨ探ラザルベカラズ。而

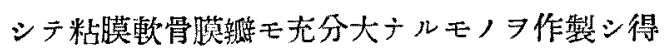
ザル場合多シ。殊二手術後第孔二於テ，穿孔八 小ナリトモ。其穿孔部附近粘膜八萎縮性ニシテ

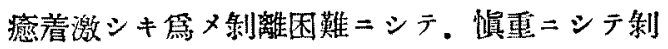

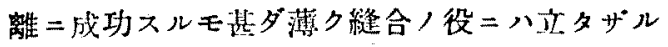

事多シ。

余八泉中隔粘膜下空形切除獄 =於厂兩側粘膜

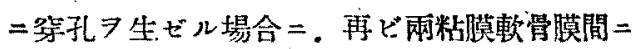
切除シタル軟督片ヨ再ビ雨入スル事ニヨリテ第 孔フ免カル、事實 $コ$ り暗示 $尹$ 得テ. 穿孔閉鎖 際=モ顿骨或八骨片移植=ヨリ，其不完全ナル 縫合 補へリ。余八最近一年牛ノ間二本法ニヨ y 6 例二試 $i 3$ 例二於于比較的好結果 7 得夕 1).

更二余，遭遇七ル鼻中隔穿孔症例中其原因， 甚ダ稀有ナリト思考七ラル、モ，2例アリ。即

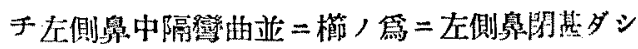

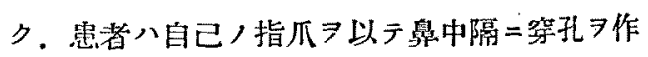

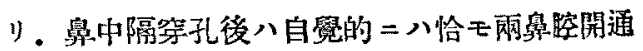
七ル如クニナレリ。郎手該患者つ舅呼吸八穿孔 ，前方二於テ八右側鼻踛及ビ第孔ヨ介シテ左側

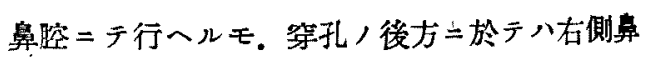
腔ノミシ以テ鼠呼吸 7 行ヘルナリ。而シテ兩人 共=自己，鼻中隔二第孔，存在七ルシ知ラザリ

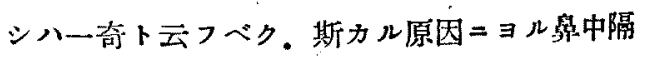
穿孔八余，寒聞ナル未ダ文献二記阵七ラレタル ヨ知ラス。茲二記シテ諸先彗＼cjkstart御批制ヨ仰ガン トスルモノけり。 


\section{第二草 症}

芽一例 患者: 松门次つ. 35蔵. 今. 職業. 毛皮 商。

主訴 : 昔㢣嘶嗄。

既往歴: 10 年前二徽毒及ビ淋病二程患セり。

家族歷：特記スベキ事無シ。

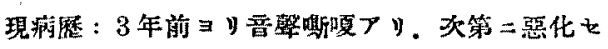

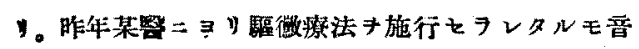

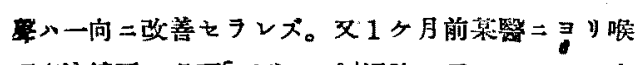
頭㨁涬鏡下二喉頭「ポソープ」切除キ受タタルモ一向

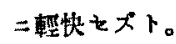

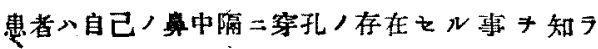

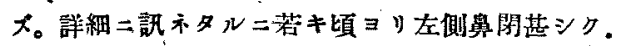

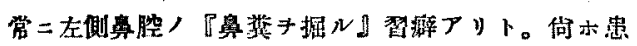
者八常二雨側小指ノ爪头約 $0.5 \mathrm{~cm}$ 程伸シ.之キ以

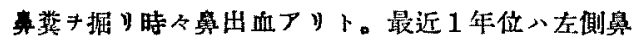
閉八稍了輕快飞、是〉。

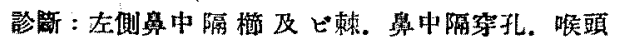
「ポリープ」。

入院：昭和15年 6 月 12 日。

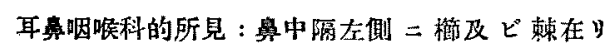

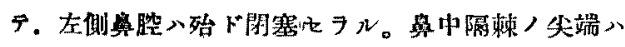

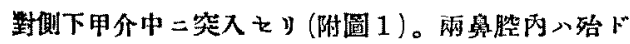
清济。奥中隔前下方二大穿孔 $(1.3 \mathrm{~cm} \times 0.5 \mathrm{~cm})$ ア リ。

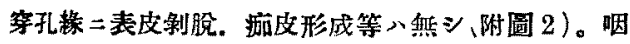
頭後壁稍了颗粓狀. 後悬孔附近清浮。喉頭八右側㢣

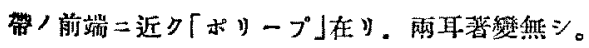

一般所見：著變キ認メズ。

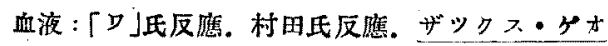

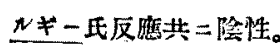

經過：6月14日，16日，18日卜3回二亘り。患者

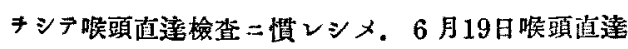
鏡下ニ「ポリープ」切除キナセり。斯クデ術後一時入

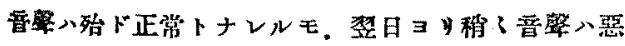
クナレリ。併シ後1過間ニシテ再ピ正尚 二恢得せ .

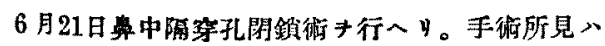
头ノ如シ。

局所醉。1\%「パンカイン」6 ca 及ヒ「アドレ +yン」6 滴，坐位二於テ行フ。

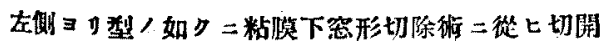

例

第 1 例 附 圆
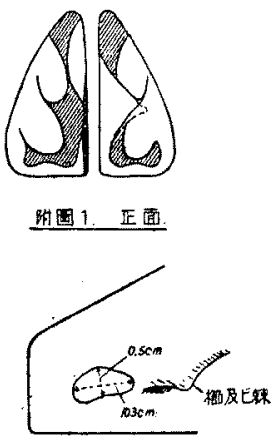

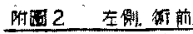

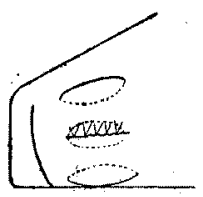

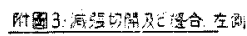
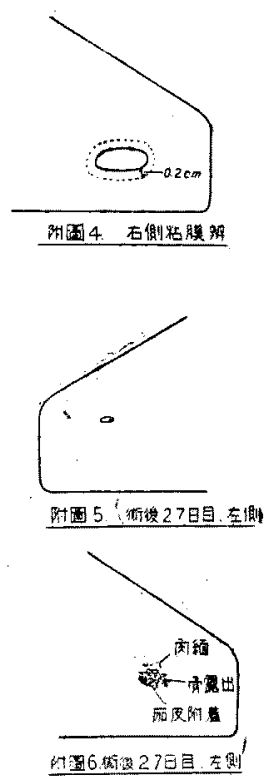

剝離キ行フ。案孔緣八其厚サ稍、厚シ。

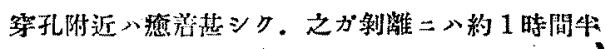

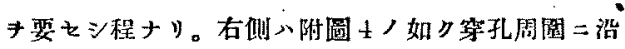

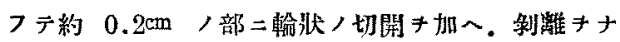

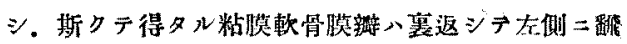
粨シ。綪合部ノ減張二役立タシメタリ。更二第孔，

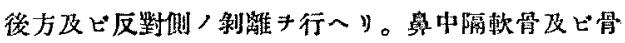

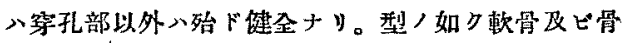

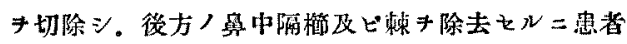

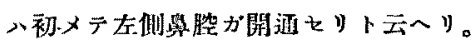

減張切開心附圆 3 , 如》二第孔，上下 $=2$ 本羁

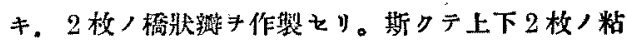

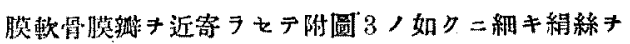
以テ 5 絲終合七り。綘合部二八箱骨垂㨁板 $コ$ り切除

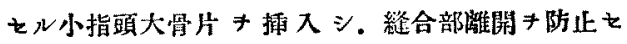

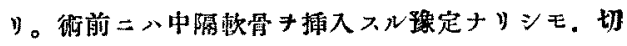
除八際二教個二破碎シ。其目的二使用シ得ザリキ。

手琎後3日間八等孔部ハ血塊二被ハレテ見メズ。 然 $=$ 術後 4 日目鼻洗後詳細二检查七ル上. 左側 3

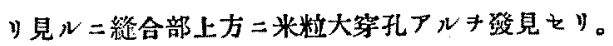
右侧二八凝血塊附落シ其上方二移植骨片少シク露仙 


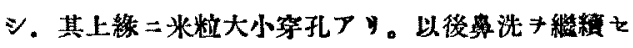
1.

6 月27日退院。化澧八肉哏的二ハ認メズ。找絲心 勧サズ. 自然二縫合綵ノ脱落スル 1。

7 月17日所見ハ附圆 5 及ビ 6 ノ如シ。郎チ吉側ョ ソ見ル時八創面八殆ド治磨シ。米稙大小案孔キ眙を ルノミ。右側ヨリ見ル時八案孔部下方二少シク站皮

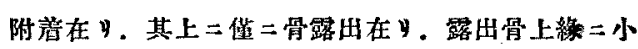

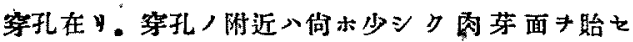
》。移植骨八白色キ是シ，㳖死二珤レルモノナラ $v_{0}$

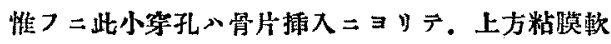

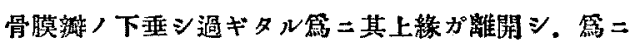

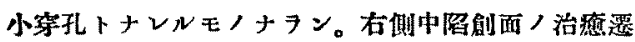

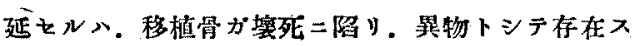
ル篇ナリ。

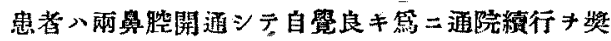
メタルモ肯ゼス，通院キ中止セり。小穿孔キ贻をル

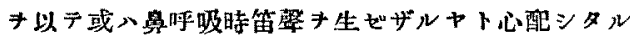
モ幸二斯力ル淀桨八無力キ。

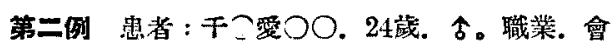
'触員。

主訴：左僛鼻闒。

既往歷. 家族糜：特記スベャ事無シ。

現病歷：4年前雨侧殊二左側悬閉ナル主訴，下=

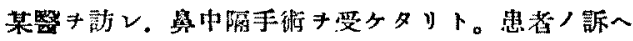

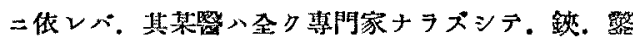
及ビ㦸、「コンとォトーム」等キ以テ突出部キ切除七

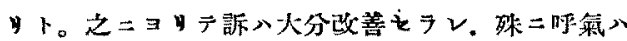

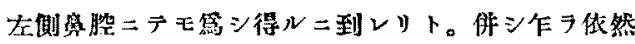
トシテ左例學閉．頭重感殊二左側前頭部遮重感アリ デ日迄鼻洗 $キ$ 續行七りト害入。

患者八自己，楀中隔二大等孔在ルキ知ラザリシモ 約 1 年前某醫二数へシレ。初メテ知リタリト。

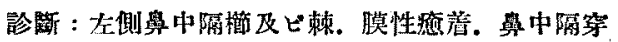
孔。

入院: 昭和15年7月23日。

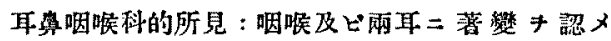
メ゙。

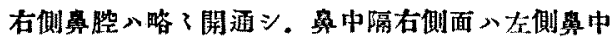

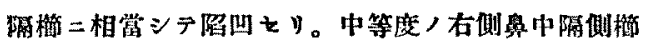

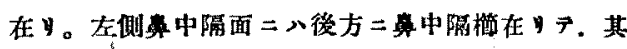

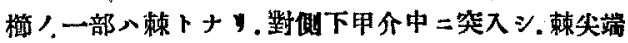

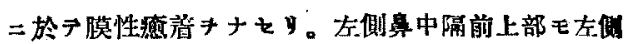

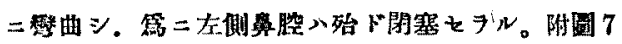
，如シ。算中隔方形㜞骨部二一大第孔 $(2.0 \mathrm{~cm} \times 0.7$ cm) 7 y. 附圆 8 及 9 /如シ。

以上ノ所見 $ョ$ 日按ズルニ. 恐ラクハ現在/穿孔部

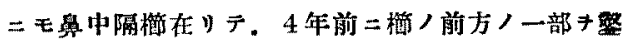

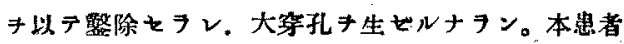

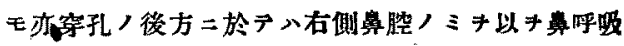

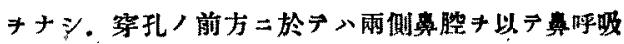

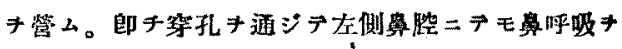

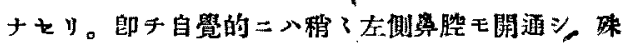

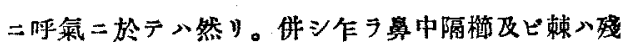

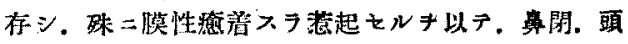
車感ノ殘存セルモ亦宣ナルべシ。

一般所見：著慗キ認メズ。

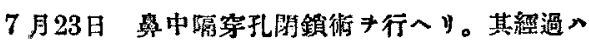
次ノ如シ。

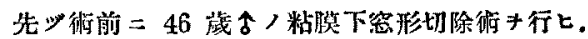

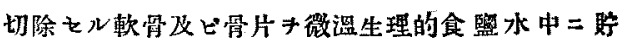
7 。

局所㒋醉。1\%「ノ゙カイン」10ca 及ビ「フトレ $ナ y ン 」 1 / 4$ 皮下針二テ 20 滴。坐位二於テ行フ。 第一切創入型/如ク左側二。可及的前方二置々 y。其下端

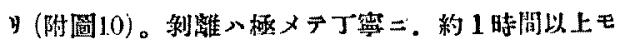

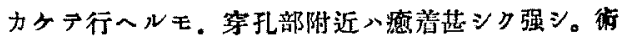

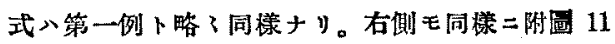
八如ク案孔線周总二沿フテ約 $0.2 \mathrm{~cm}$ ，距離二翰狀

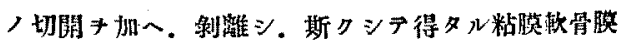

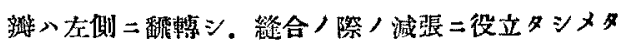

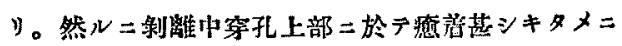

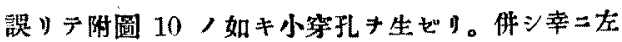

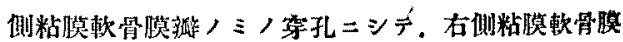

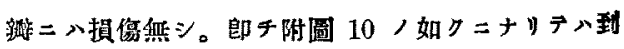
底完全ナル縫合ハ不可能卜ナレリ。

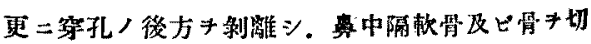

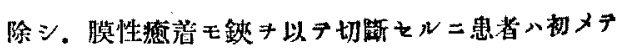
雨鼻谐力゙開通七り卜鹤喜せり。

斯クテ完全絺合ハ不可能ナルキ以フ附國 12 ，如

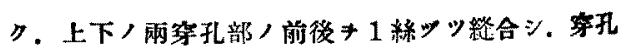




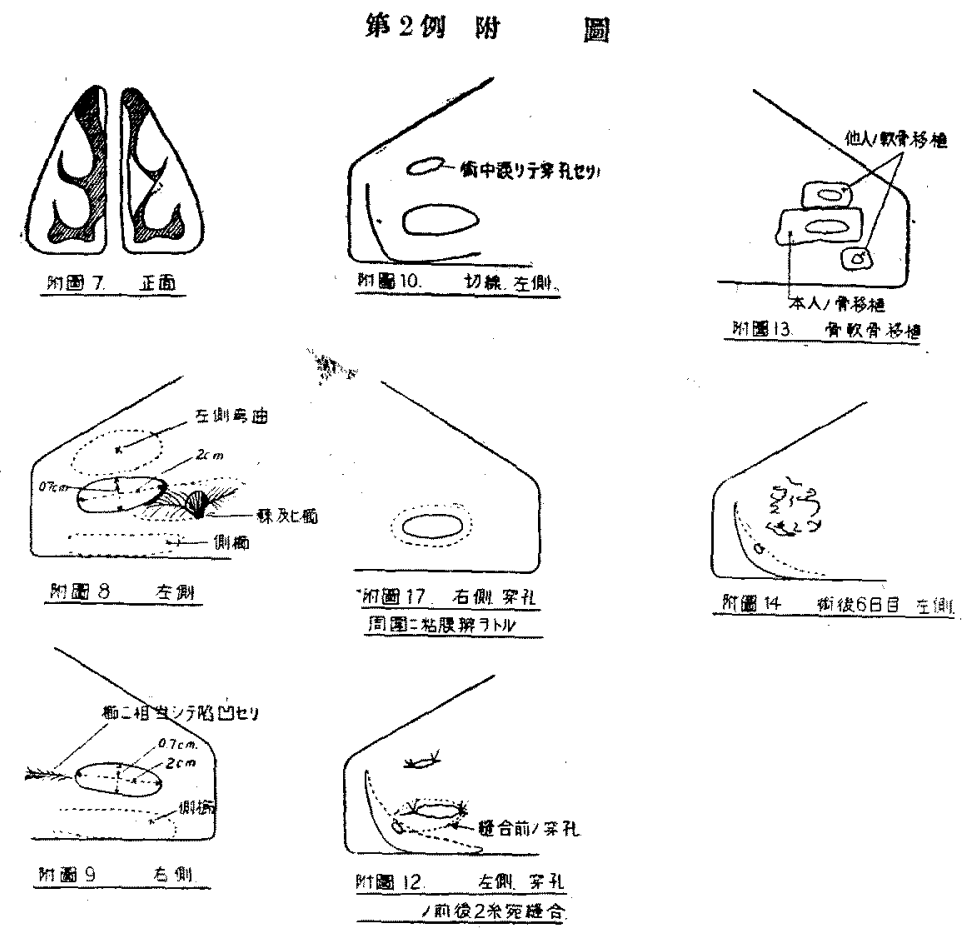

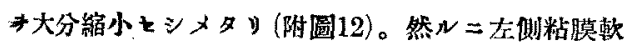

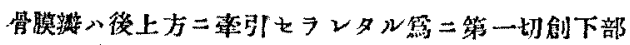

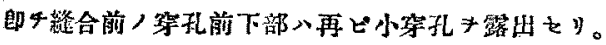
跑圈引12

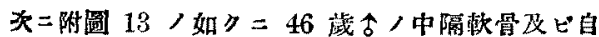

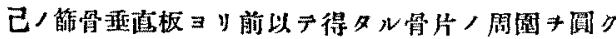

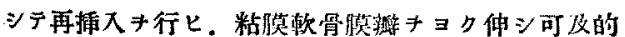

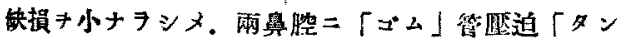
ボン」キ挿入シ街キ了をり。

7 月 25 日.「ゴム」管「ダンポン」キ除タ二。架 中陆手獄部八㠜血塊二被ハレテ見エス゚。

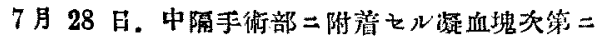

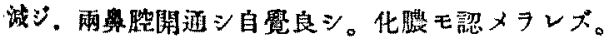
然

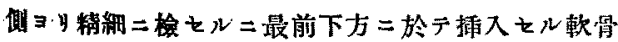
片ハ移動シ。該部二小穿孔キ生でリ（附圆1甘!。拔称 ハ行ハメ゙。自然脱落キ街ッ。

7 月 29 日本日退院セシメタルニ夜间何等訜因卜

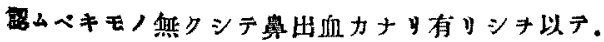
再入院れり。

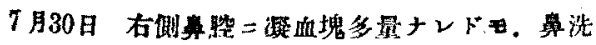

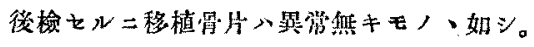

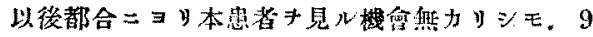

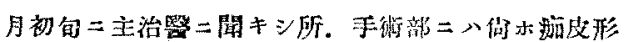
成カナり存スルモ。等孔八前下部ニ小ナルモ，1個

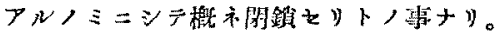

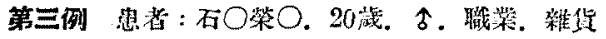
辩。

主訴：象㭔吸時ノ笛㢣(ビービー)。

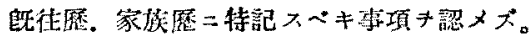

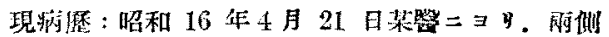

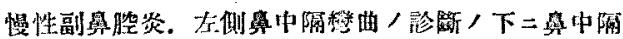
粘膜下空形切除術 吸時二「ビービー」卜笛㢣キ磁ス卜。而シデ此笛㯏

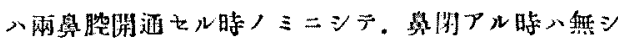

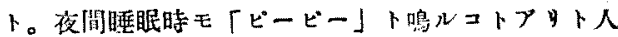

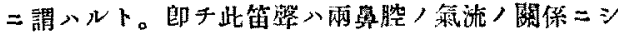

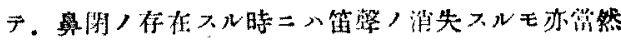
事产。

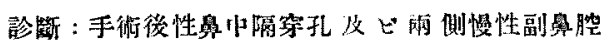
炎。

入院：昭和16年5月30日。 


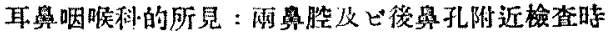

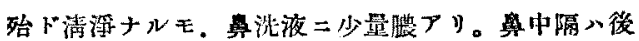

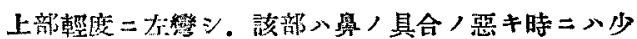
シク䦌塞スト。舞中缡中部前方ョリ約 $1.3 \mathrm{~cm} /$ 所二 米粒大穿孔アリ。其附近珠二前下方キ一ゼルバッハ

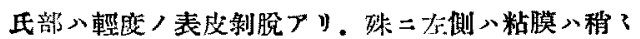

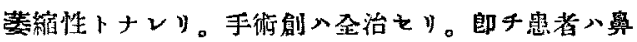

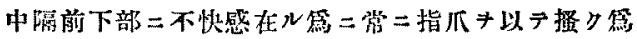

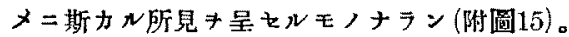

一般所見：持記アベキ事無シ。

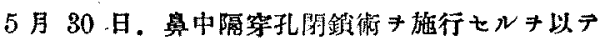
手術所見及ビ其後つ䌌過キ略記セン。

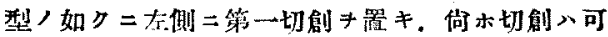
及的前方二皮虚部二器》。其下端八悬腃底二本行二 後方二延長セり。附圆 16 /如シ。剥崔入穿孔/前

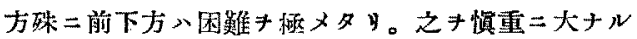

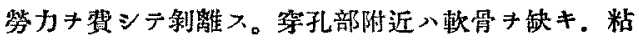

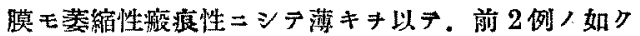

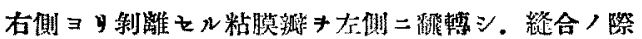
八減張二役立》入事入不可能ナルキ以テ斯カル操作

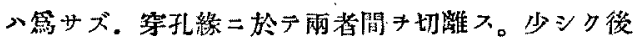
方ニ入レバ軟骨モ殘存シ。制嚁モ通管”粘膜下空形

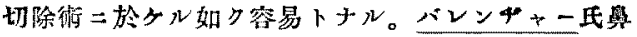

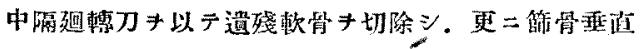

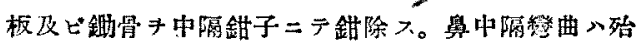
ド治洂セり。貝クテ指頭大骨片 1 個及ビ小指頭大㳄

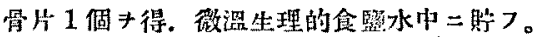

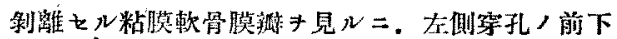

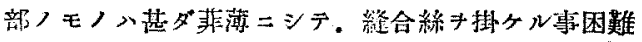
ニジ其用キナサズ。故二附圆 16 人 a b c /如ク

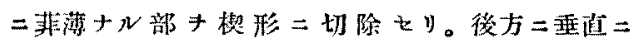

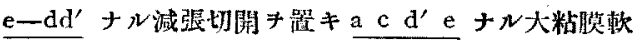

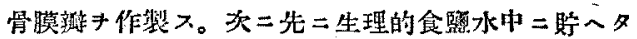
ル指頭大骨片キ附圖 18 ，如ク二穿孔部二插入せリ。 即于之キ右侧ョリ兒ル時八白色ナル小豆大骨露出面 ＼cjkstart見儿。左側二於テ八 a c d e ナ 丰前方二移動シ。附圖 17 ノ如ク二ab及ビ $\mathrm{ac} \neq$

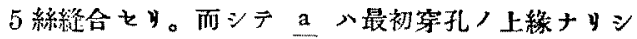

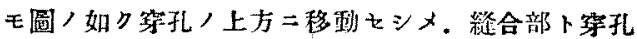
部! 合致スルキ防ゲ、。

第一切刢部壬附圆 17，如》二4絲維合七り。各

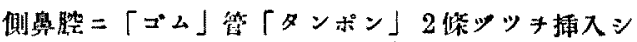

第 3 例 附圆
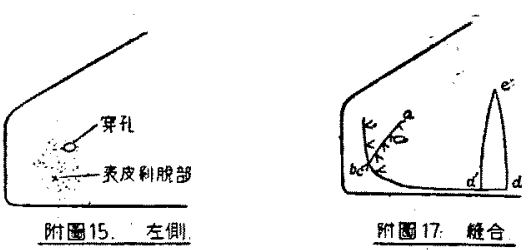

阴圈 17: 椎合
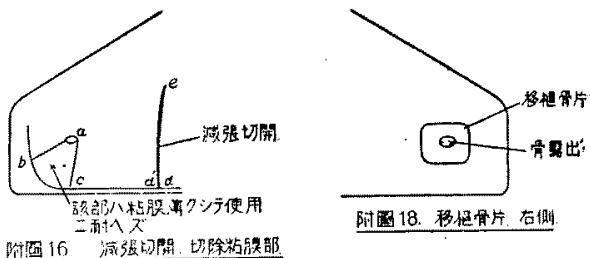

県キアをリ。

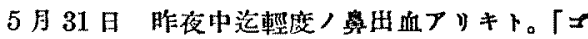
ム」管「タンボン」チ拔去セルニ手衔部二八颎血塊

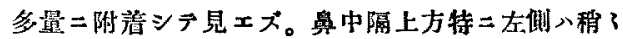

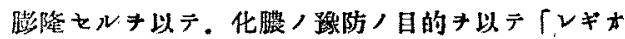
ン」注射キ速日行へリ。3日間入微熱アリシ主以後

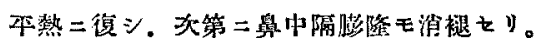

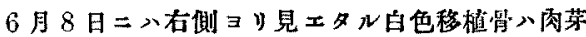

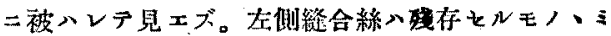
“絲拔䋨七り。其他八自然二脫落れルナラン。

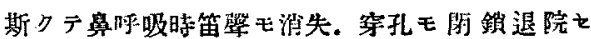

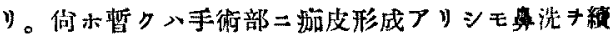
行スル中二头第二減少七り。

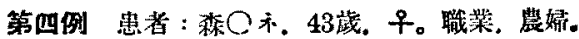
初臸：昭和16年5月28日。 主訴：左侧鼻朕內疼痛。

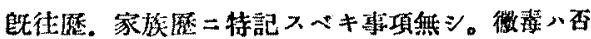
定之り。

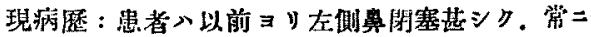

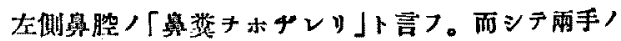

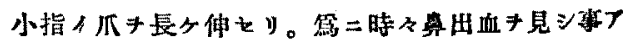

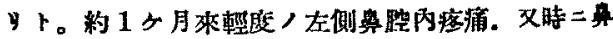

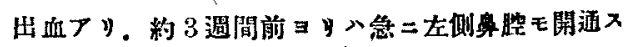

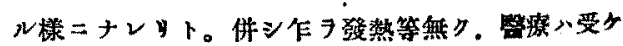

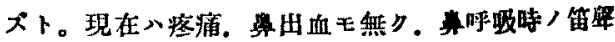
等王無シト。左側鼻呼吸可能トナレルキ以テ具合良 シト言フ。何ホ5月 13 日某病院ニデ俭セN=「可

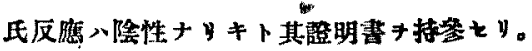




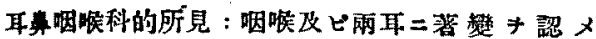

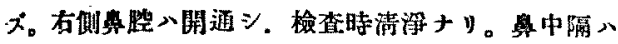

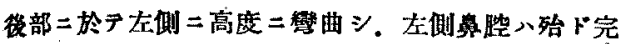

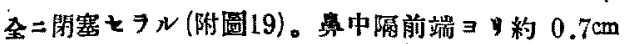
八所二大豆大驾孔在、，既二穿孔綵八上皮化シ。本

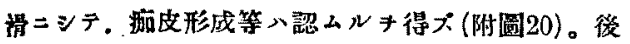

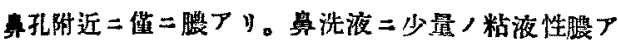
i).

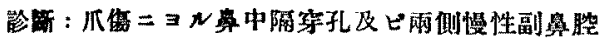
类。

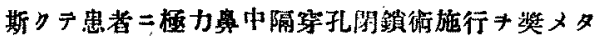

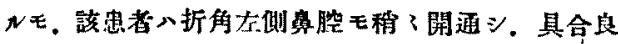
クナリタルナ以テ. 久現在八農繁期ニシテ多忙ナル キ以テ手術キ拒絕七り。

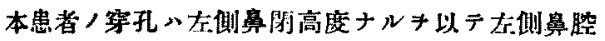

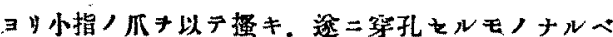

シ。而シテ其得孔称過入的 $7-10$ 日位二シテ. 此间二

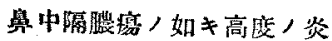
流キ噫起セザリシハ宰ナ

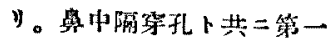
及ビ二例，如ク，案孔，後

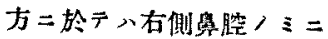
テ鼻呼吸キ營ミ。穿孔ノ前

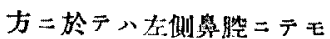
呼吸管么モノニシテ. 斯 カル奇現参，焦二患者，悬

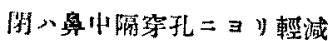
セフレタルナリ。

本例八其留中隔穿孔原因 ノ珍シキキ以テ穿孔阙鎖 、 拒絕をタレ果サザリシモ記檥をルれノナリ。

\section{第三章 總括並二考按}

\section{蔃一苗 隔穿孔ノ原因二就テ}

鼻中隔穿孔八㱠ド總テ後天性二起ルモノニシ テ.之タ明カ二セルハッっケルカンドルナリ。 其原因ア列舉七バ次ノ如シ。

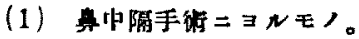

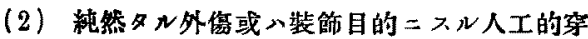
孔 $=\exists N モ ノ 。$

（3）中隔自身，急性炎症二ヨルモ。

（4）急性傅染病（例へバ麻疹.「インフルェン ザ、天然痘、水痘、「チフテリー」、「チフス等)二

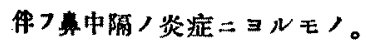

（5）特發性禹中隔轻患 $=\Xi ル モ ， 。$

(6) 狠狖及ビ結核

(7) 得表

（8）娥莱性二來タルモノ。

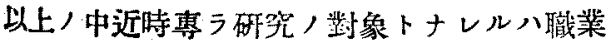

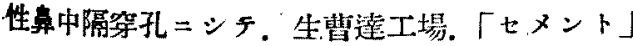
工場。金㴊砂紙，整造所. 莯料他素工場，石灰 㙂工境.「クローム」含有物

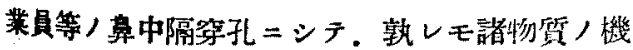

峨的或八化學的刺战。乾懆等=ヨルモノ =シテ 其第孔機序八特發性鼻中隔穿孔二類似

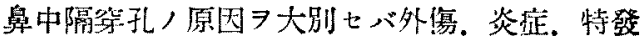
性鼠中隔第孔ノ三者卜ナル。

余八最近 1 年牛, 間 $=7$ 例，鼻中覆穿孔二遭

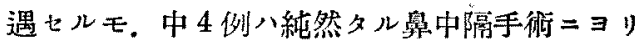
發生七ルモノニシテ. 他 1 例八舅中隔手衔後

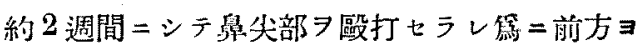

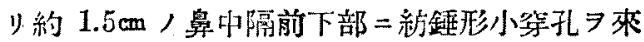
タセり。其附近ニ八少シク溢血 認メ。恰モ鼓 膜，外傷性学孔二於ケルガ如シ。其他，2例小 赤趏二述ベントスルモノナリ。

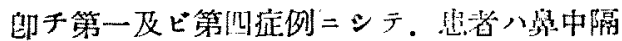

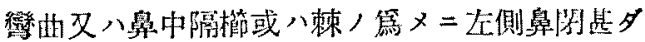

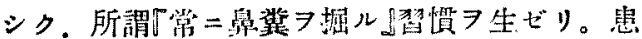
者八本邦人 = ヨ夕見ラル、奶夕.小指ノ爪䄪

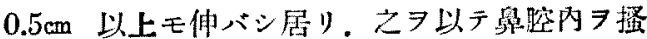
爬七り。斯クテ人工的二舜中隔案孔作り．左 
側㩊呼吸障碍习輊減セシメタルナリ。第孔七ル 後八第孔，後方二於テ八右側二於テ曹う界呼吸 ヨ營i，等孔，前方二於テ八左側鼻腔二於テモ 亦鼻哦吸ヨ營メルナリ。而シテ舅呼吸障碍ノ整 減八吸氣時二於ケルヨリ呼军時二於ケル方ガ著 明ナルハ諭习俟タザルナリ。即千第二症例患者 ノ訴へタルが如シ。

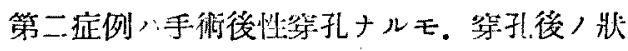
態八第一，四症例卜全ク同ジ。

其等孔機序: 考按スル二所謂特發性鼻中隔第 孔二稍 ? 似タリ。所謂特發性鼻中隔第孔ト ジーベンマンガ乾性前鼻炎ト稱シ。ハエックガ 第孔性鼻中隔潰济! 命名セルモノニシテ. 初 メ鼻中隔前下部郎チ所謂キービルバッハ氏部二 粘膜乾燥。汸皮形成 $尹$ 來タシ。橫色或八赤褐色 タ呈ス。郎チッッケルカンドルノ所謂「キサン トーゼ」ナリ。患者八鼻內乾燥. 瘙封. 或八泇 皮形成 $=\exists$ ル不快感。學呼吸障碍等 $=\exists$ リテ舅

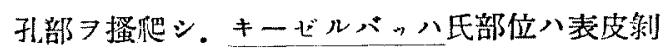

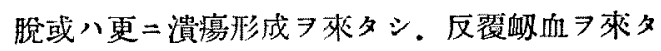

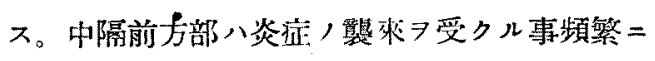

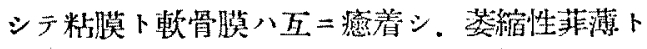

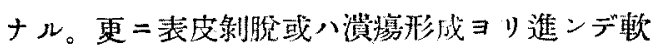
骨八露出，破壞七ラレ第孔トナル。

余，例=於テ八其籍孔經過入之卜似タルモ， ナランモ. 穿孔原因，主ナルモノ八小指ノ爪二

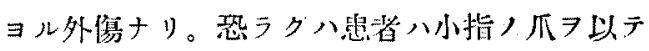
鼻腔內八所々ラ䗗舥七ルナランモ。最モ抵抗， 弱キ秋中隔=第孔ヨ生ゼルモノナラン。此爪，

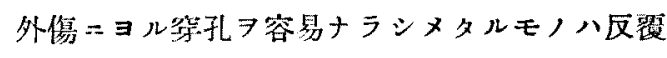

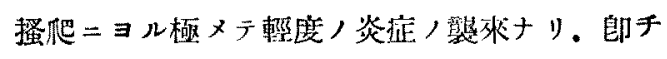
所謂特發性鼻中隔第孔二モ稍 $<$ 似タルモ。外傷

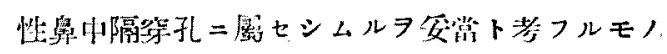

ナリ。此第孔經過，比較的著明ナリシ八第四庭 例ナリ。第一症例二於テ，穿孔後長期閒經過女 ルラ以テ，其訴へモ著明ナラズ。其穿孔經過後 ノ狀態八純粹, 外傷 $=ヨ$ ル第二证例ノ夫レトハ

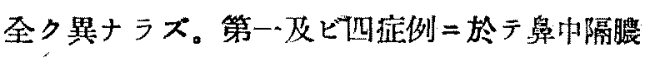
瘍等习莌起七ザリシハ幸㞄ナリ。

從來特發性鼻种隔第孔ト考へラレタルモ，、 中ニ八以上，如キ症例モ存在セシナラン。本邦 人二見ラル、小指ノ爪ヨ長ク伸バシ。耳搔キノ

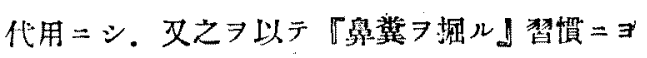
ル被害,最大ナルモイナリ。

\section{第二藍 曾中隔/穿孔閉鎖二就テ}

臭中隔紫孔閉鎖手衔術式トシテ記载セラレタ ルモノ八極メテ尠シ。更二多クハ小第孔閉鎖二 適常七ルモノニシテ.大符孔二對シテハー定， 術式八䇥キモ，、如シ。之八鼻中隔第孔八其小 ナル時八鼠呼吸時笛整例人八゙第三症例，如り存 在シ。患者八訴へトハナリ得ルモ。大第孔二於テ

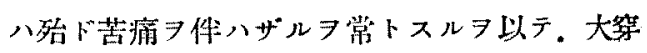
孔閉鎖，機會二遭遇スハント尠事事. 及大第孔.

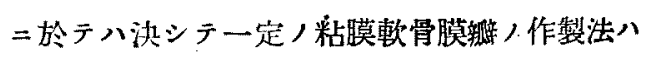

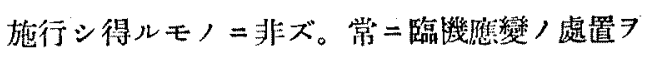
探ラザルベカラズ。即チ個々，場合ニョリテ皆

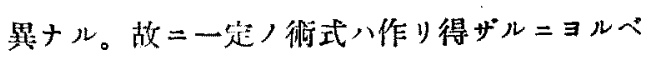
シ。更二粘膜軟学膜瓣作製方法八剩離 7 終了シ テ㢺ニ. 初メテ決定シ得ルモノニシテ、小第孔 ト雖モ。剩離二失收スル時八大穿孔卜同等，困 難习來タスモノナり。故二小呀孔卜踓モ從來 ヤンカウェル氏法. ハルレ氏法.ザイフェルト 氏法、レヴィス氏法等ノ優劣习論シ。 又一定， 方法二準㨸シテ行フコトハ多ク，場合二於テハ 不可能ナリ。余八未ダザイフェト氏ノ下甲介

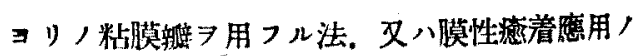


閴法八行ヒタルコト热キ x.

次=鼻中隔等孔閉鎖，難易八其等孔゙ ‘小二

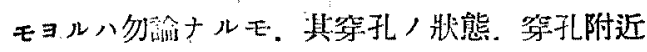

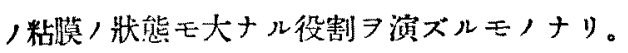
即手穿孔線附近，粘膜八殆ド健常ニシテ．表皮

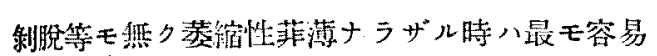
シシテ。重二等孔部以外二䡉骨，殘存スル時八 軟骨，存在丈儿部分八通掌，鼻中隔粘膜下空形

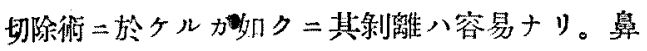

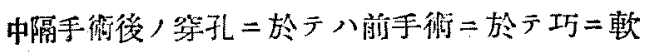
骨膜下二於テ剩犁七ル部分八再手術時ニ於テモ

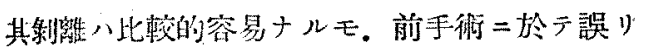

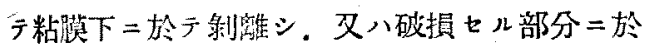
‘八制離八非常二困菶ナり。殊二知孔附近＝於 可恰モ乾燥性前奥炎，如キ狀態トナルモノ=於

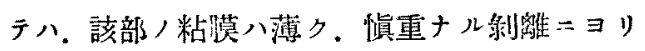
成助スルモ，其粘䠑八菲薄ニシテ到底䋃合，用 二八立タズ。故二手術後第孔二於テモ腎者二堅 夕皇内择爬 7 禁ジ。該部，乾燥性前鼠炎，如キ 狀態ノ治癒七ル骁二行フベキモノニシテ。決シ テ功习急グ可カラズ。

總テ絴合二際シテハ創面ト創面トタ合セテ綎 合スベキ八諭ヨ俟タズ。俳シ乍ラ殊=日本人= 於ケル如ク狄率空內二於テ動モスレバ切レ易

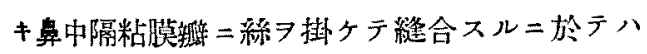
斯カル事八最モ幸運ナル場合二於テ可能ナル事 ニシテ、多ク，塨合二於テハ不可能ナリ。故二

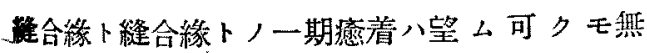

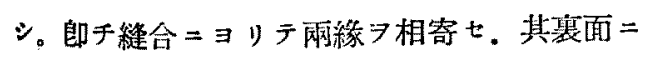
於テ反對側粘膜軟骨膜ニヨリえヨ支持セシメ離 開七ザル栐 $=$ ス。郎于鼻中隔粘膜下穴形切除術 二於テモ一侧/粘漠堹骨膜損稘ハ決シテ等孔

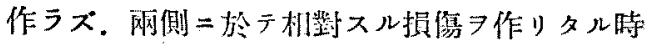
ニ初メテ第孔トナル。

即チ本手狱，眼目ト七ル所八娍張切開 $=\exists ル$

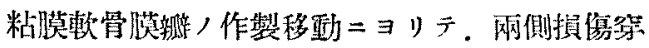

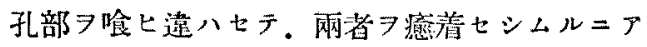

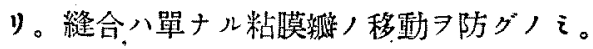
粘膜数，作製八前述，如》。剩離終了=ヨ》 テ初メテ決定シ得ルモノニシテ。減張切開モ適 宜ニス可キモノナリ。後方絽切閐=ヨリ後方

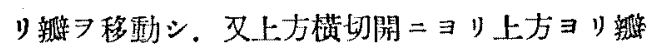
フ移動シ。文前方ョッスル壬可ナリ。更二鼻险 底粘膜フ用フルモ。文反對側粘漠习用フルモ可

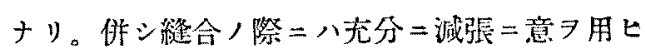
ザル可カラズ。制離終了後二於テ最適，方法 探用スベキナリ。制離八通常困嚾フ極ムルモ，

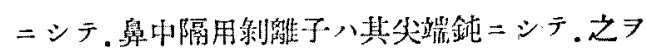
用フル時八自然卜力入ル事二ナリ。損傅习來タ

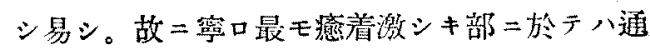

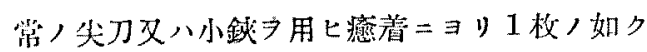
ニナレル兩粘膜 7 䊺二離開シテ 2 校トナスガ如 キ感〉リ。縫合部八粘膜軟骨膜㲔作製二當り。 可及的閉方二来儿栐二七ザル可力ラズ。鼠空内 深部二於ヶル綎合卜．鼠腔大口部附近二於ヶル 䋖合卜从其難易サ二於テ格段, 州造アルラ以テ

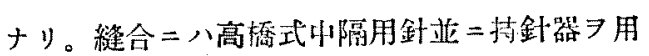
フルフ最モ使トス。綎命絲八余八通学，粘能用

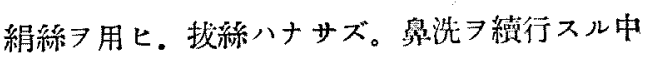
二自然㝂落スル 徍ツ。

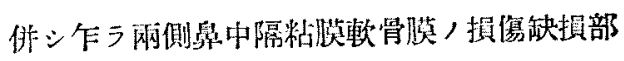
ヨ喰ヒ違ハス事ハ言フハ易クシテ行つハ難シナ

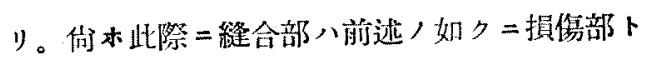
看做サ、ル可カラズ。故二网側粘膜軟骨膜，間 二挿大シ。其支持組織トナリ，縫合部，離開 
防グモノアラバ大イ =便ナり。其狀態 $ル=$. 粘膜下空形切除術 $=$ 於テ兩側 $=$ 損鹪 7 來 タセル場合二似タリ。此際＝八切除靶骨，再挿 人ハヨク其第孔 ヨ防グモノナリ。余八此文持組 糡トシテ本人文他人，鼻中隔ヨリ切除七几犁 骨片及ビ骨片ヲ用ヒタリ。

遊離軟骨片又八遊離骨片，移植，可否. 又八 移植セラレタル骨片或ハ軟骨片ノ運命二關シテ 八百諭，存スル所ニシテ.'文献上ノ記載モ枚舉 二遈無シ。余/目的トスル所八鼠中隔兩葉間= 挿入セル軟骨片或ハ骨片が異物トナリテ，鼻中

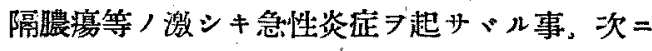
絪中隔兩葉間二於テ挿入七ラレタル骨片或八軟 骨片が支持組織トナリ．粘膜軟骨瓣ハ之二稳着 シテ其移動フ防止サル、事。更二粘膜軟骨膜缺 損ニョリテー部，露出七ル骨面或八軟骨面八後 二到り次第二肉芽 7 以テ被ハレ其上=更二上皮 化七ラル、事ナリ。上皮化終了後二於ケル，即

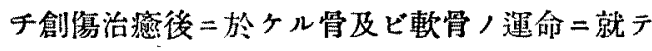
八問題ナラズ。㐭背其他八整形，目的=使用七 ル骨或八軟骨等上八自ラ其目的习異ニセり。移 植骨或八敷骨が吸收七ラル、トモ。 刃一部八破 壞一部八新生ニョリ結局八新生骨或八軟骨二置 換セラル、トモ敦レニテモ佳シ。

鼻中隔粘谟下怒形切除術後兩葉粘膜間 $=$ 軟骨 再挿入 八第孔防止，目的二ハ非ズシテ彼八鼻中隔粘膜 下空形切除石媵八學中隔八其支持 7 失ヒ浮動 7 來タシ. 不快ナル症候习喚起スルラ以テナリ。 此再捙入, 可否八別問題トシテ. 手息時, 穿孔

\section{第四草 蛣}

1. 余八最近長ク伸バャル手小指爪二ヨル爪
防止八目的 7 以テスル再插入八其後多クノ人々 ニョリテ試えラレ. 推獎セラル、所ナリ。

既 $=$ 片岡氏八京都府立醫科大學雜誌第 1 卷 $=$ 於テ鼻中隔手術後，洽癒機轉二關シ詳細ナル算 驗的研究 7 發表セり。其中，移植軟骨片 ス儿穿孔防止實驗，項二於テ次，如ク进へタ リ。民八 3 頭/家鬼二於テ該菑驗 7 試i 1 例= 於テ八移植軟骨，移動=ヨリ失敗七ルモ他， 2 例二於テ，完全二成功セリト。而シテ网側粘膜

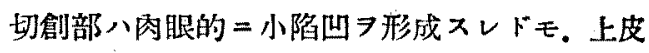
八䠶=此部二モ延長被镜 骨，運命二就テハ移植軟骨八壤死=陷ルモ. 新 生軟骨 八運命二就キテモ移植骨片=於テモー一部=八吸 收ヨ.他ノ一部ニ八骨新生ヨ認メタリト。

余ノ插入七ル軟骨片及ビ骨片/運命モ同樣タ ラン。而シラ兩者共 =移植セラレ. 其支持組織 トシテノ役目ア果スモノナリ。骨軟骨搟入二祭 シテ最モ注意スへキ八挿入媵移植骨或八軟骨片 ノ移動 シシテ此目的ニ八患者二絕對安靜 7 命

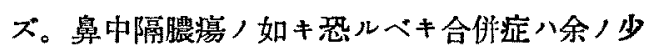
數 八.艖驗=於テハ無シ。斯カ儿第孔，減张切閉 等ニヨリ䚇所二開放七ラレ居ルラ以テ鼻中隔脤

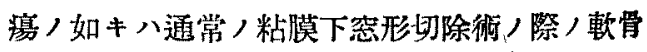
片再捚入，場合ヨリ更二稀ナルモノナルベシ。 此軟骨或八骨移稙ノ缺點トモ言フペキモ， 八. 移植片八單二挿入セルノえナルラ以テ初メ

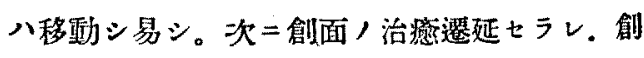
面附近二八長ク㴦皮形成

\section{猃}

稘 
遇七リ。

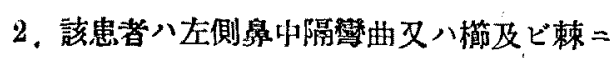

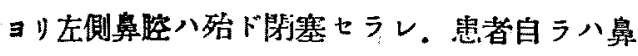
中隔穿扎ニヨリ左側鼻呼吸モ可能トナレリト考 一居りタリ。併シ賽八等孔，後方二於テ八右侧

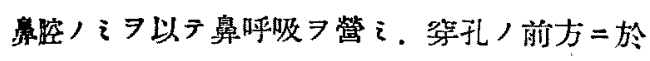

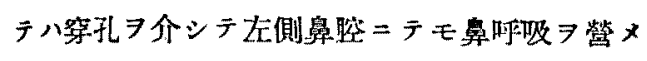
ルモノリリ。

3. 余八最近數例 $=$ 於亏鼻中隔第孔門鎖街 7 施行主，3例二於テ好結果习得タリ。

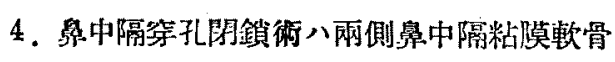

膜ニ於ケル蚗損部

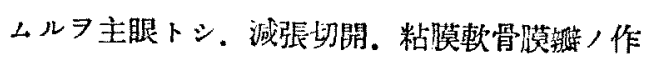
製方法い場合々タ二應ジ適宜ニナスべキモ， ナリ。

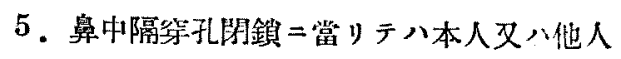
，鼻中隔軟骨片又八骨片，鼻中隔兩葉間再塖入 八粘膜軟骨膜蜼，支持組織トシテ大 ルモノナリ。露出骨或八敷骨部モ媵二八次第二 肉芽 $=$ 被ハレ更 $=$ 其上ヨ上皮化セラル、モノナ り。

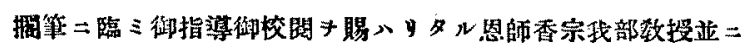

猿源助教授二謝意表入。

交

1) Pasaow: Denker.Kahler's Handbuch Bd. II Luftwege usw. II S. 494-509. 2) Seifrert: 'Die Operationslehre v. A. Seiffert S. 146 . 3) 片网

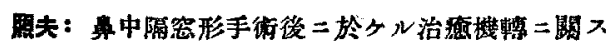

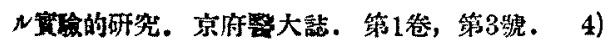

跍

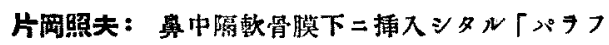

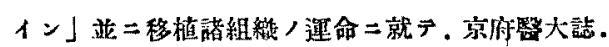

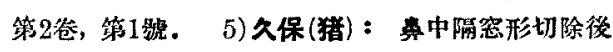

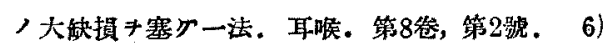

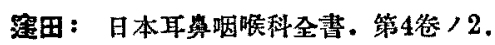

